\title{
DUA SISI GELAP COVID-19 : DILEMATIS ANTARA KETERBUKAAN DATA IDENTITAS PENDERITA COVID-19 DAN TRANSPARANSI DATA PUBLIK DALAM RANGKA MENEKAN STIGMATISASI (PERSPEKTIF DARI SEGI SOSIOLOGI)
}

\author{
Yohanes Firmansyah', Imam Haryanto ${ }^{2}$ \\ ${ }^{1}$ Fakultas Hukum Kesehatan, Universitas Pembangunan Nasional Veteran Jakarta. \\ ${ }^{2}$ Fakultas Hukum, Universitas Pembangunan Nasional Veteran Jakarta \\ ${ }^{1}$ yohanesfirmansyah28@gmail.com, ${ }^{2}$ imam.haryanto@upnvj.ac.id
}

\begin{abstract}
The Covid-19 case has had a huge influence on all aspects of human life, starting from health, economy, sosial, law, and many more. The COVID-19 pandemic has caused various frictions between various interests, one of which is a clash between individual interests and community interests. One of the obvious things about this problem is regarding the impact of COVID-19 in the field of sociology, especially the relationship between individuals, especially the issue of community stigmatization regarding infectious diseases, the dilemma between the privacy rights of the identity of COVID-19 patients and the disclosure of publik data on COVID-19 patients with various risks will injure and cause multiple material and immaterial losses. On the other hand, Covid-19 also raises various sosial-psychological problems and legal problems that still do not regulate all aspects of human life. This paper describes the sociological elements of COVID-19, the right to privacy, publik information disclosure, and the sosial-psychological impact of COVID-19, along with a juridical review of the right to privacy and publik disclosure of information regarding the transparency of COVID-19.
\end{abstract}

Keywords: Privacy Rights; Stigmatization; Information Disclosure; Covid-19; Sociology Of Law

\section{Abstrak}

Kasus Covid-19 telah menyebabkan pengaruh yang sangat besar di seluruh aspek kehidupan manusia dimulai dari aspek kesehatan, ekonomi, sosial, hukum, dan masih banyak lagi. Pandemik COVID-19 ini menimbulkan berbagai gesekan diantara berbagai kepentingan, salah satunya adalah benturan antara kepentingan individu dan kepentingan masyarakat. Salah satu hal yang nyata dari permasalahan ini adalah mengenai dampak COVID-19 pada bidang sosiologi terutama hubungan antar individu terutama permasalahan stigmatisasi masyarakat mengenai penyakit infeksius, dilematis antara hak privasi identitas pasien COVID-19 dengan pembukaan data publik pasien COVID-19 dengan berbagai risiko yang akan mencederai dan menyebabkan berbagai kerugian material dan immaterial. Disisi lain, Covid-19 juga menimbulkan berbagai permasalahan sosial-psikologis serta permasalahan hukum yang masih belum mengatur seluruh aspek kehidupan manusia. Makalah ini memaparkan dengan rinci mengenai aspek sosiologi COVID-19, hak privasi, keterbukaan informasi publik, dan dampak sosial-psikologis akibat COVID-19, beserta tinjauan yuridis antara hak privasi dan keterbukaan informasi publik dalam hal transparansi COVID-19

Kata Kunci: Hak Privasi; Stigmatisasi; Keterbukaan Informasi; Covid-19; Sosiologi Hukum 


\section{Pendahuluan}

Sejak Desember 2019, terdapat serangkaian kasus pneumonia yang tidak dapat dijelaskan di Kota Wuhan, Cina. Pemerintah dan peneliti Tiongkok telah mengambil langkah cepat untuk mengendalikan epidemi serta mencari etiologi dari pneumonia misterius tersebut. Pada 12 Januari 2020, World Health Organization (WHO) memberikan terminologi terhadap virus baru tersebut sebagai Novel Coronavirus 2019 (2019-nCoV). Tepat pada tanggal 30 Januari 2020, WHO mengumumkan status epidemi infeksi 2019-nCoV dan memberikan peringatan telah terjadi keadaan darurat kesehatan masyarakat serta menjadi permasalahan serius di tingkat internasional. Pada 11 Februari 2020, WHO secara resmi memberikan terminologi kelainan akibat 2019-nCoV sebagai Corona Virus Disease 2019 (COVID-19). Pada waktu yang bersamaan, Coronavirus Study Group (CSG) yang merupakan bagian dari Komite Internasional mengenai Taksonomi Virus menyebut 2019-nCoV sebagai Severe Acute Respiratory Syndrome Coronavirus 2 (SARS-CoV-2). (AHC Media, 2020) Kasus infeksi SARS-COV-2 hingga tanggal 16 Agustus 2020 telah menginfeksi 21,026.758 kasus diseluruh dunia dengan kematian total mencapai 755.786 jiwa. Negara dengn infeksi SARS-COV tertinggi ditempati oleh Amerika Serikat dengan 11.271.215 kasus, Eropa 3.733.965 kasus, Asia Tenggara 2.971.104 kasus, Eastern Mediterranean dengan 1.710.272 kasus, dan Afrika dengan 936.062 kasus. (World Health Organization, 2020) Negara Indonesia sebagai bagian negara Asia Tenggara melaporkan 139,549 kasus terkonfirmasi, 40.296 dalam perawatan, 93.103 sembuh dan 6.150 meninggal (CFR : 4,4\%) pada tanggal 16 Agustus 2020. (Kemenkes RI, 2020)

Joko Widodo selaku presiden Indonesia berkomitmen untuk menanggulangi permasalahan pandemic COVID-19 ini sesegera mungkin dengan berbagai Langkah strategis yang dalam penanganannya membentuk Satuan Penanganan Covid-19 dibawah kendali Badan Nasional Penanggulangan Bencana (BNPB) yang selanjutnya diubah menjadi Satuan Tugas Penanganan COVID-19 yang bekerja di bawah pengawasan Komite Penanganan COVID-19 dan Pemulihan Ekonomi Nasional. Adapun Langkah strategis yang ditetapkan dari awal hingga kini adalah berupa penanganan pasien yang terkonfirmasi COVID-19, pemberlakuan pembatasan sosial berskala besar (PSBB) terutama pada daerah dengan angka insidensi tinggi, cuci tangan dan hygiene yang rutin, penutupan akses keluar negeri. Seluruh peraturan tersebut tertuang dalam Keputusan Presiden Nomor 11 Tahun 2020 mengenai Penetapan Kedaruratan Kesehatan Masyarakat terkait Covid-19 (Presiden Republik Indonesia, 2020a) yang dalam implementasinya dituangkan dalam Peraturan Pemerintah Nomor 21 Tahun 2020 tentang Pembatasan Sosial Berskala Besar dalam Rangka Percepatan Penanganan COVID-19. Seiring dengan berjalannya waktu, Adapun seluruh peraturan tersebut berubah dari terminology PSBB menjadi New Normal serta yang terakhir berupa Adaptasi Kebiasaan Baru.(Presiden Republik Indonesia, 2020b)

Ditengah pelaksanaan penanngulangan tersebut memicu berbagai bentuk reaksi di masyarakat yang umumnya disikapi sebagai tingkat ketakutan yang berlebihan serta memicu sikap persekusi kepada beberapa kelompok tertentu dengan risiko tertular COVID-19 salah satunya adalah tenaga kesehatan (dokter, perawat, dan profesi lainnya yang terkait). Salah satu bentuk nyata dari Tindakan pengusiran dan persekusi tersebut adalah seperti kasus tenaga kesehatan yang bekerja di RSUD yang bertempat tinggal di Indekost yang mengalami pengusiran oleh pemilik kost dan warga setempat dikarena kekhawatiran mereka akan kelompok populasi tinggi risiko tersebut (populasi kunci). (Ravianto, 2020)

Disisi lain, ditengah pergejolakan yang terjadi di masyarakat, terdapat berbagai permasalahan yang mulai timbul yaitu apakah etis dan diperbolehkan secara hukum ditengah masa Pandemi global ini untuk membuka data diri atau identitas pasien yang terkonfirmasi COVID-19 ke masyarakat luas dengan berbagai kemungkinan yaitu memicu meningkatnya kejadian persekusi yang tidak hanya terjadi pada pasien tetapi dapat meluas menjadi Tindakan 
persekusi kepada keluarga pasien oleh masyarakat. Dilema mulai terjadi dikarenakan sebenarnya data rekam medis berupa identitas diri dan diagnose pasien bersifat rahasia dan tidak boleh dibuka untuk publik kecuali dengan perintah persidangan. Adapun delik hukum ini diatur oleh Permenkes No. 269/ Menkes/Per/III/2008 mengenai rekam medis.

Disisi lain desakan masyarakat mengenai tranparansi data akan sebuah peristiwa merupakan sebuah hal yang wajib dan dianggap sebagai sebuah hak masyarakat dalam memperoleh informasi yang seluas-luasnya dikarenakan era globalisasi yang sudah dewaasa. Tuntutan masyarakat ini akan menimbulkan permasalahan dan benturan dari dua sisi aspek utama yaitu berupa aspek privasi pribadi dan aspek kepentingan atau keterbukaan informasi ke publik. Dalam era Pandemi COVID-19 ini hal ini menjadi sebuah dilemma dan permasalahan yang sangat besar dikarenakan sebenarnya dalam Pasal 57 ayat 2 dalam Undang-Undang Nomor 36 Tahun 2009 mengenai Undang-Undang Kesehatan Nasional tertuang hak atas pribadi atau yang bersifat privat tersebut menjadi tidak berlaku bilamana perintah tersebut diamanatkan oleh Undang-Undang dan untuk kepentingan masyarakat.

Seluruh pembahasan diatas telah memaparkan adanya benturan terhadap persoalan sosial dan hukum yang krusial dan kritis dengan aspek bahasan berupa mana yang lebih penting dan harus diutamakan di era Pandemi Covid-19 ini. Hak privat serta perlindungan informasi sendiri menjadi sebagai sebuah bentuk dari Hak Asasi Manusia yang idealnya harus dijunjung tinggi seperti dalam bentuk kerahasian rekam medis, serta promblematika keterbukaan data kepada publik sebagai bentuk tranparansi data dan percepatan penanggulangan Pandemi Covid-19 yang selanjutnya dapat memicu berbagai masalah sosial yang bersifat strategis di masyarakat. Jurnal ini akan membahas seputar tema mengenai: COVID-19 Sebagai Bencana Sosial, Stigmatisasi dan Diskriminasi Terhadap Penyakit Menular, Konsep Sosiologi Hak Privasi, Sudut Pandang Aturan Hukum Nasional sebagai Jembatan Penghubungan Hak Informasi Publik dan Pembukaan Identitas COVID-19, dan Evaluasi Sebagai Jalan Tengah dalam Mengatasi Konflik Kepentingan akan Keterbukaan Informasi dan Kerahasian Identitas Pasien Covid-19

\section{Metode}

Penelitian ini meninjau permasalahan berdasarkan sosiologis dengan metode kualitatif denga tipe penelitian yuridis normatif. Adapun yang dimaksud penelitian hukum kualitatif dengan tipe yuridis normatif berupa penelitian yang dilakukan dengan cara telaah serta analisis terhadap data-data berkaitan dengan aturan dan peraturan serta data tentang kegiatan sosial kemasyarakatan yang disimpulkan secara deduktif dari berbagai pernyataan yang ada dalam berbagai sumber data sekunder seperti bahan tulisan Pustaka (literatur, buku, jurnal, dokumen tertulis) atau bahan hukum sekunder (perundang-undangan, teori-teori hukum, putusan pengadilan terdahulu, doktrin, pendapat ahli hukum) yang seluruhnya relevan serta berkaitan dengan permasalahan utama yang dibahas dalam jurnal ini. Pendekatan yang dipakai dalam penelitian ini berupa 3 pendekatan yang diawali dengan pendekatan perundang-undangan, pendekatan secara konseptual, dan pendekatan analitis. Spesifikasi penelitian ini berupa preskriptif-analitis yang seluruh sintesis data, pembahasan, dan kesimpulan data dianalisis dengan sebuah pendekatan besar berupa penelitian kualitatif (Ibrahim, 2006)

\section{Hasil dan Pembahasan}

\section{COVID-19 Sebagai Bencana Sosial}

Pertumbuhan populasi dan efek virus yang begitu besar mendorong kita kepada keadaan yang disebut sebagai salah satu krisis kesehatan dan ekonomi terburuk sepanjang sejarah manusia. Mungkin kengerian itu pertama kali menjadi jelas bagi khalayak global pada Februari - Maret ketika berita dari Italia utara, wilayah makmur yang merupakan pusat awal epidemi, memuat cerita tentang rumah sakit yang penuh dengan kasus COVID-19. Segera 
setelah ini muncul cerita tentang perawat dan dokter yang terlibat dalam triase, memilih siapa yang akan mendapatkan perawatan, dan menolak orang yang sangat sakit, terutama orang tua, yang dibiarkan pulang dan meninggal. (Rosenbaum, 2020) Kekurangan kit pengujian, masker, respirator, alat pelindung diri, fasilitas rumah sakit, dan perlengkapan lainnya segera menjadi pokok pelaporan COVID-19. Di Indonesia, kepanikan masyarakat awalnya tergambar sebagai pembelian masker dan hand-sanitizier secara besar-besaran yang menyebabkan stok berbagai produk tersebut menjadi hilang di pasaran. (Sampurno et al., 2020)

Ini adalah bencana sosial di tingkat yang paling buruk dikarenakan metode penyebaran COVID-19 adalah kontak sesama manusia. Berbagai protokol pemerintah telah dibentuk untuk menekan angka penyebaran covid-19 salah satunya adalah "Physical Distancing" yang berfokus dalam pencegahan penularan COVID-19. Permasalahan sosial yang ditimbulkan tidaklah berhenti sampai disana, tetapi berbagai kebijakan negara di dunia mulai membatasi kebebasan berkumpul dan kebebasan dalam berekonomi guna menekan angka penyebaran COVID-19 yang berdampak pula terhadap berbagai permasalahan sosial mulai dari hak asasi manusia, ekonomi, hak privasi dan keterbukaan informasi. (Kementerian Kesehatan Republik Indonesia, 2020; Sampurno et al., 2020; Suni, 2020)

Berbagai permasalahan sosial lanjutan yang terjadi adalah membiarkan para imigran India tanpa gaji, makanan, atau transportasi pulang karena alasan ekonomi (Santhosini, n.d.), benturan lain yang terjadi adalah permasalahan pemaksaan pemakaian masker dan larangan berkumpul yang dianggap oleh Sebagian besar orang melanggar hak asasi manusia, serta permasalahan kegawatdaruratan medik yang memaksa para tenaga kesehatan untuk "memilih pasien potensial" yang secara kemanusian memang tidak layak untuk dilakukan tetapi sulit untuk tidak dilaksanakan dikarenakan keterbatasan fasilitas. (Satya, 2020)

Salah satu permasalahan sosial yang cukup menarik untuk dibahas adalah mengenai desakan masyarakat umum mengenai publikasi identitas pasien COVID-19 demi kepentingan Bersama tetapi disisi lain, kebijakan ini akan berdampak terhadap mencederai hak privasi manusia. Secara sosial memang benar bahwa keterbukaan identitas diri akan meningkatkan kewaspadaan masyarakat akan COVID-19 tetapi tidak jarang bahwa pembukaan identitas diri ini akan berdampak terhadap tindak persekusi akibat stigamtisasi masyarakat mengenai penyakit infeksi khususnya infeksi COVID-19

\section{Stigmatisasi dan Diskriminasi Terhadap Penyakit Menular}

Stigma sosial dalam konteks kesehatan adalah hubungan negatif antara seseorang atau sekelompok orang yang memiliki kesamaan ciri dan penyakit tertentu. Dalam suatu wabah, ini mungkin berarti orang-orang diberi label, distereotipkan, didiskriminasi, diperlakukan secara terpisah, dan / atau mengalami kehilangan status karena dianggap memiliki keterkaitan dengan suatu penyakit. Perawatan semacam itu dapat berdampak negatif bagi mereka yang menderita penyakit, serta pengasuh, keluarga, teman, dan komunitas mereka. Orang yang tidak mengidap penyakit tersebut tetapi memiliki karakteristik yang sama dengan kelompok ini mungkin juga menderita stigma. Wabah COVID-19 saat ini telah memicu stigma sosial dan perilaku diskriminatif terhadap orang-orang dari latar belakang etnis tertentu serta siapa pun yang diduga pernah melakukan kontak dengan virus tersebut.(Bhattacharya et al., 2020)

Stigma seputar COVID-19 berasal dari fakta bahwa banyak yang tidak diketahui tentangnya. Ilmuwan, peneliti, dan profesional medis di seluruh dunia masih bekerja dengan sangat cepat untuk mencari tahu strategi untuk menangani kebaruan virus ini. Ketakutan akan yang tidak diketahui telah membanjiri umat manusia secara evolusioner. Manusia cenderung menjauhkan dan memisahkan diri dari yang tidak diketahui. Setiap kali ada kekurangan penjelasan, baik itu ilmiah atau supernatural, individu yang terkena dampak telah dipisahkan, diberi label, dan distigmatisasi, dan karenanya, dikucilkan sebagai konsekuensinya. (Bhattacharya et al., 2020; Connell, 2020) 
Stigma sosial terhadap kaum tersegregasi tampaknya merupakan perilaku yang wajar bagi masyarakat umum. Ia memperoleh penerimaan sosial di tengah-tengah kekacauan yang tidak diketahui. Pemisahan institusional dari mereka yang terkena suatu penyakit, pada COVID-19 saat ini, semakin memperkuat stigma tersebut. Kami menyadari stigma sosial yang dialami oleh mereka yang dirawat di panti sakit jiwa, kusta, HIV Aids, atau TBC, bahkan hingga saat ini.(Bharat, 2011; Trani et al., 2015) Pencegahan COVID-19 pun menuntut segregasi; istilah seperti karantina, jarak sosial, dan isolasi telah menjadi bagian integral dari kosakata rumah tangga. Rumah sakit telah dialokasikan khusus untuk pengobatan COVID-19, laboratorium terpisah telah ditetapkan, zona karantina telah ditetapkan, zona penahanan telah dibuat, dan negara telah dibagi menjadi zona warna tergantung pada tingkat insiden. Memang, ini adalah langkah-langkah untuk meratakan grafik yang terus naik. Namun, karena pandemi lebih dari sekadar fenomena biomedis, semua langkah ini juga memiliki implikasi sosialnya sendiri. (Krishnatray, 2020)

Insiden stigmatisasi sosial terhadap mereka yang terkena COVID-19, termasuk anggota keluarganya, marak terjadi. Orang-orang yang meninggal karena penyakit telah ditolak upacara pemakamannya. Dalam banyak kasus, keluarga telah menolak untuk menerima jenazah, dan pemerintah negara bagian telah melakukan kremasi sebagai gantinya.(Bajpaii, 2020; Sharma, 2020) Sebagai tindakan terhadap perilaku pengucilan seperti itu, beberapa bahkan mengeluarkan perintah untuk mengajukan tuntutan pidana terhadap siapa pun yang menghalangi pemakaman jenazah covid-19.(Chavan, 2020) Banyak insiden terungkap di mana para penyintas telah diisolasi oleh lingkungan, memaksa mereka untuk menjalani kehidupan yang terasingkan dari biasanya. Dilabeli dengan banyak tag seperti "penyebar" hanya memperburuk penderitaan mereka.(Ram, 2020) Gejala medis COVID-19 bukanlah salah satu permasalahan di masa pandemic, tetapi permasalahan yang lebih besar timbul dari segi sosial yang berdampak terhadap permasalahan psikologi Covid-19. (Patel et al., 2020)

Stigma tersebut ditujukan tidak hanya kepada mereka yang telah sembuh dari COVID19, tetapi menyerang juga pada seluruh tingkatan penyakit dimulai pada kelompok yang sedang menjalani pengobatan, melakukan pemeriksaan Covid-19, bahkan pada kelompok keluarga penderita Covid-19. Beban stigma sosial juga dihadapi oleh pekerja garis depan, praktisi medis, perawat, personel polisi, tantara, dan masih banyak lainnya. Mereka dipaksa meninggalkan lingkungan dan ditolak akses ke rumah mereka dan keluarga mereka pun diancam. Stigma sosial telah mengalahkan niat baik orang-orang yang mereka perjuangkan.(Bharat, 2011)

Stigma sosial terhadap kelompok marginal tertentu seperti gelandangan atau buruh migran juga terlihat. Saat kembali ke rumah setelah berbulan-bulan terdampar di berbagai bagian negara, para pekerja dan keluarga mereka telah diasingkan, diejek, dan dilecehkan oleh anggota masyarakat. Di beberapa tempat, mereka telah diusir bahkan setelah menyelesaikan karantina wajib selama 14 hari.(Kumar \& Mohanty, 2020) Hal ini menjadi double burden pada penyakit Covid-19 bilamana disandingkan dengan penyakit lain yang menimbulkan stigmatisasi masyarakat seperti tuberculosis, HIV/AIDS, dan Penyakit kusta. (Bharat, 2011)

Keadaan darurat kesehatan masyarakat, seperti wabah COVID-19 ini, tentu menimbulkan tekanan bagi masyarakat. Ketakutan dan kecemasan terhadap suatu penyakit dapat menyebabkan stigma sosial terhadap orang, tempat, atau hal lain. Tentunya, beberapa kelompok rentan terhadap stigma, seperti, pasien suspek, personel medis, bahkan pasien yang telah dinyatakan sembuh sekalipun. Stigma sosial dapat menimbulkan penolakan sosial, diskriminasi dalam edukasi, pelayanan kesehatan, pekerjaan, hingga menimbulkan kekerasan fisik.(Connell, 2020; Krishnatray, 2020)

Terdapat beberapa hal yang dapat dilakukan untuk melawan stigma dalam respons COVID-19 ini, namun yang paling penting adalah menjaga kerahasiaan identitas pasien sebagai tanggung jawab fasilitas medis dan pemerintah. Tak dapat dipungkiri, di tengah ketidakpastian keadaan wabah, kebutuhan akan informasi dan data menjadi kebutuhan yang 
mendesak. Seperti yang telah disinggung sebelumnya, perhatian yang cukup perlu diberikan pada bagaimana informasi data tersebut ditangani karena individu terkait dapat menghadapi stigmatisasi ataupun diskriminasi apabila informasi terkait dirinya, terlebih dengan hasil tes positif, bocor kepada publik.(Bharat, 2011; Ram, 2020) Selain dampak negatif pada pasien, dampak lainnya yang perlu dikhawatirkan adalah memberikan rasa malu atau takut akan diskriminasi pada pasien COVID-19 lainnya untuk maju memeriksakan penyakitnya sehingga dapat menyebabkan pemerintah lebih sulit lagi untuk mengendalikan wabah ini. Stigma dapat dilawan dengan mengedukasi masyarakat dan melawan informasi yang salah.(Bharat, 2011; Kumar \& Mohanty, 2020; Ram, 2020)

\section{Konsep Sosiologi Hak Privasi}

Konsep privasi memiliki sifat yang universal dengan pengaturannya di berbagai negara dalam bentuk tertulis (undang-undang) dan tidak tertulis (moral). Samuel Warren dan Louis Brandeis (1980) dikenal sebagai orang pertama yang mencetuskan konsep hak akan kebutuhan privasi yang tertuang dalam sebuah makalah yang berjudul "The Right to Privacy". Samuel dan Louis juga memaparkan bahwa salah satu hak individu adalah untuk hidup sendiri atau dikenal dengan "right to be let alone" yang menjadi sebuah salah satu issue strategis dari Hak Asasi Manusia (HAM). Warren mengungkapkan bahwa hak privasi merupakan sebuah hak yang harus mendapatkan perlindungan oleh hakim serta perlindungan akan data pribadi (identitas hingga riwayat medis) merupakan sebuah hal yang sangat krusial untuk dilindungi dikrenakan menyangkut harga diri dan kebebasan dalam berekspresi.(Dewi, 2016) Berzonson berpendapat bahwa hak privasi atas data pribadi merupakan sebuah konsep hukum dalam upaya menghargai hak privasi.(Bezanson, 2017) Kelalaian atas perlindungan privasi terutama dalam hal identitas diri akan menimbulkan kerugian secara materil maupun immateril. (Priscyllia, 2019)

Deklarasi atas Hak Asasi Manusia yang dicanangkan oleh Association of Southeast Asian Nations (ASEAN) berpendapat bahwa perlindungan privasi data pribadi sebagai sebuah hak privasi yang harus dilindungi. Hingga makalah ini ditulis, sudah tercatat 75 negara yang mengatur mengenai perlindungan data pribadi secara khusus. The Council of Europe Convention for the Protection of Individuals with regard to Automatic Processing of Personal Data (No.108), 1981; the Organization for Economic Cooperation and Development Guidelines on the Protection of Privacy and Transborder Data Flows of Personal Data (1980); the Guidelines for the Regulation of Computerized Personal Data Files (General Assembly Resolution 45/95 and E/CN.4/1990/72); and the General Declaration of Human Rights; the International Convention on Civil and Political Rights; The General Data Protection Regulation (EU) 2016/679 (GDPR) menggantikan aturan yang dibuat The Data Protection Directive 95/46/ EC mengatur mengenai berbagai hukum internasional yang menekankan akan prinsip fundamental dari perlindungan data pribadi (privasi) yang selanjutnya diratifikasi oleh berbagai negara dengan berbagai penyesuaian. Bukti adopsi hukum internasional dari berbagai negara seperti yang dilakukan oleh,Personal Data Law di Filipina, Data Protection Law di Sungapura, Personal Information Protection Law di Korea Selatan, Information Technology Regulation di India, Personal Data Protection Law di Jepang, Law on Protection of Personal and Electronic Document Information di Kanada, Personal Data Protection di Argentina. dan masih banyak lagi contoh dari berbagai negara yang mengadopsi peraturan international mengenai pentingnya perlindungan atas privasi data pribadi yang tertulis dalam European Union Rules dari The Organization for Economic Operation Development (OECD). (Tejomurti et al., 2019)

Pandangan mengenai konsep hak privasi dari sudut pandang sosiologi dan antropologi ialah hak privasi merupakan bentuk permintaan dari individu, sekelompok orang hingga masyarakat mengenai kapan dan bagaimana (keadaan khusus) sebuah data pribadi seseorang dapat dikemukakan di depan umum atau khalayak banyak (publik). Alasan pentingnya sebuah 
data pribadi perlu untuk dilindungi adalah hak privasi merupakan hak bulat seseorang dan pemenuhan akan hak tersebut tidak didasarkan kepada hak orang lain, tetapi hak tersebut dapat hilang bilamana pemilik hak tersebut menghendaki publikasi informasi tetapi seseorang tetap berhak untuk tidak membagi informasi pribadi mengenai masa lalu maupun kehidupan sosial. Disisi lain, hak privasi juga menjadi tidak berlaku bilamana informasi tersebut melingkupi atau mempengaruhi kehidupan publik atau khalayak banyak karena informasi tersebut mungkin saja dapat sebagai pelindung dari segi sosial khalayak banyak. Tetapi pelindungan mengenai hak privasi beserta kerugian yang ditimbulkan dari sisi pembukaan identitas diri perlu dibicarakan dan dibahas lebih mendalam guna memfasilitasi dan menekan kerugian sekecil mungkin dari seluruh pihak terkait.(Tejomurti et al., 2019)

Privasi sendiri menyangkut tiga prinsip yang essensial yaitu mengenai prinsip "right to be alone", prinsip privasi akan pencatatan yang dilakukan oleh orang lain, dan prinsip privasi atas segala bentuk komunikasi yang dilakukan dengan media online. Ketiga prinsip tersebut akan menuai berbagai macam pelanggaran pada tiap klasifikasinya, seperti pelanggaran pada prinsip pertama atau"right to be alone" yang merupakan konsep utama dari hak privasi. Adapun contoh 4 jenis pelanggaran pada prinsip pertama adalah menampilkan seseorang baik dalam bentuk foto maupun media lainnya pada waktu dan tempat yang tidak sesuai, mempublikasi data pribadi (baik nama, nomor telepon, dan sebagainya) untuk tujuan komersial, menyebarluaskan "aib" pribadi kepada publik, dan tidak memberikan ruang dan waktu untuk seorang individu sendirian. Contoh pelanggaran prinsip kedua yang berhubungan dengan informasi data pribadi yang ditulis oleh orang lain seperti informasi catatan criminal, informasi pajak dan asuransi, kebiasaan seseorangm rekam medis dan sebagainya yang disalahgunakan dengan maksud untuk kepentingan pribadi. (Tejomurti et al., 2019) Peninjauan dari segi pembukaan informasi pasien COVID-19 akan berdampak terhadap gesekan pada pelanggaran hak privasi bilamana tidak diatur dengan benar

\section{Sudut Pandang Aturan Hukum Nasional sebagai Jembatan Penghubungan Hak Informasi Publik dan Pembukaan Identitas COVID-19}

Sudikno Mertokusumo menguraikan Hak sebagai sebuah kepentingan yang harus dilindungi dengan pengertian kepentingan berupa sesuatu hal yang bagi individu maupun masyarakat diharapkan agar dilindungi serta memiliki arti kekukasaan yang hendaknya dijamin serta dilindungi keberadaannya oleh aturan atau hukum dalam hal pelaksanaannya. (Mertokusumo, 2005) Sementara itu makna dari kata informasi sendiri berasal dari asal katanya yang berupa "informare" yang dalam bahasa Inggris berarti "Inform" yang menjadikan informasi adalah sebagai sebuah alat atau media pemberitahuan atas suatu hal baik berdasarkan pandangan pribadi maupun pendapat akademis (berdasarkan pengetahuan). Undang-Undang Republik Indonesia Nomor 14 Tahun 2008 tentang Informasi Publik (Rev. Keterbukaan Informasi Publik) yang menimbang beberapa hal berupa informasi adalah bagian dari kebutuhan essensial bagi setiap insan guna pengembangan pribadi dan lingkungan sekitarnya khususnya sosial dan berperan penting untuk ketahanan nasional serta hak untuk mendapatkan informasi merupakan bagian dari hak asasi manusia serta keterbukaan akan informasi kepada publik merupakan salah satu bentuk demokrasi dengan menjujung tinggi kedaulatan rakyat; Disisi lain, keterbukaan publik juga dapat digunakan sebagai sarana dalam mengoptimalisasikan fungsi pengawasan publik akan penyelenggaraan Badan Publik dan Negara serta memiliki dampak terjadap kepentingan publik. Selanjutnya mendefinisikan sebuah informasi sebagai bagian dari keterngan, gagasan, tanda, dan pernyataan yang didalamnya mengandung akan pesan, makna dan nilai, baik dalam bentuk fakta, data, atau penjelasan yang terkait serta dalam penyampaiannya informasitersebut dapat dibaca, didengar, atau dilihat dengan berbagai bentuk penyajian atau kemasan (format) yang relevan dengan perkembangan teknologi, ilmu pengetahuan dan komunikasi baik media cetak maupun 
elekronik. Undang-Undang Nomor 14 Tahun 2008 juga menguraikan pandangan mengenai Informasi Publik adalah informasi yang dihasilkan, disimpan, dikelola, dikirim, dan/atau diterima oleh suatu badan publik yang berkaitan dengan penyelenggara dan penyelenggaraan negara dan/atau penyelenggara dan penyelenggaraan badan publik lainnya yang sesuai dengan Undang-Undang ini serta informasi lain yang berkaitan dengan kepentingan publik. (UndangUndang Republik Indonesia Nomor 14 Tahun 2008 Tentang Keterbukaan Informasi Publik, 2008)

Menurut Teori Hukum Nasional (sebuah pengantar hukum) diketahui bahwa regulasi melakukan penggolongan terhadap Informasi atas Kesehatan kedalam dua ranah yaitu aspek hukum publik dan privat. (Mertokusumo, 2005) Penelusuran lebih mendalam membagi aspek hukum publik menjadi aspek hukum publik umum dan khusus. Aspek hukum publik yang bersifat umum dalam informasi kesehatan mencakup segala bentuk layanan rumah sakit atau fasilitas kesehatan baik primer, sekunder, dan tersier serta didalam layanan fasilitas kesehatan tersebut seperti biaya, mekanisme pelayanan, standar operasional prosedur (SOP), fasilitas kesehatan, dan system pembiayaan (BPJS dan asuransi lainnya). Hal lain yang termasuk aspek hukum publik yang bersifat khusus adalah mengenai laporan atau kronologis perjalanan sebuah penyakit, tindakan pencegahan dan penanggulangan penyakit, promosi kesehatan, deteksi dini penyakit, riwayat perkembangan dan perjalanan penyakit, studi epidemiologi serta pola penyebaran dan penularan penyakit, zona merah atau episentrum penyakit, dan seluruh informasi yang bersifat khusus lainnya yang wajib dibuka ke publik sebagai informasi publik karena telah diatur dan diamanatkan oleh perundang-undangan. Informasi kesehatan ang masuk dalam aspek hukum privat diantaranya segala sesuatu yang berhubungan dengan data yang terkandung dalam rekam medis yang meliputi data diri pasien yang lengkap, anamnesis (riwayat perjalanan penyakit, riwayat penyakit terdahulu, riwayat penyakit keluarga, riwayat sosial, riwayat pengobatan, dan lainnya), hasil pemeriksaan yang relevan dan objektif baik fisik maupun penunjang (laboratorium, fisiko-medic, pencitraan radiologi, dan sebagainya), diagnose, tata laksana, prosedur Tindakan, dan prognosis.

Rekam medis adalah sebuah hal yang sangat penting dan krusial dalam pelaksanaan dan penyelenggaraan kesehatan di Indonesia. Pengertian Rekam medis menurut Permenkes No: 269/MENKES/PER/III/2008 adalah dokumen yang didalam berkas dokumen tersebut terdapat data-data dalam bentuk catatan seperti identitas pasien, hasil pemeriksaan fisik dan penunjang, riwayat medis dan pengobatan, serta Tindakan medis yang telah diberikan kepada pasien tersebut. (Kementerian Kesehatan Republik Indonesia, 2008) Hal rekam medis ini diatur dalam Pasal 29 Ayat (1) huruh "h" Undang-Undang Republik Indonesia No. 44 Tahun 2009 tentang Rumah Sakit yang didalamnya mengatur "Setiap Rumah Sakit mempunyai kewajiban menyelenggarakan Rekam Medis" (Republik Indonesia, 2009a)dengan penegasan di dalam UU lanjutan yaitu Pasal 70 dan Pasal 71, UU No. 36 Tahun 2014 tentang Tenaga Kesehatan yang menjelaskan bahwa setiap tenaga kesehatan yang memberikan pelayanan kesehatan kepada individu diwajibkan untuk membuat rekam medis (Pasal 70 bulir 1); rekam medis tersebut haruslah segera dilengkapi setelah pelayanan kesehatan selesai dilaksanakan (Pasal 70 bulir 2), dan rekam medis haruslah mengandung data nama, waktu, paraf atau tanda dari tenaga kesehatan yang memberikan pelayanan medis tersebut (Pasal 70 bulir 3), serta disimpan dan dirahasiakan oleh fasilitas kesehatan (Pasal 70 bulir 4). Kepemilikan rekam medis adalah milik Fasilitas Kesehatan serta yang boleh dibawa keluar fasilitas kesehatan (transfer) hanyalah dalam bentuk resume medis (Pasal 71 bulir 1-2) (Republik Indonesia, 2014)

Seluruh ketentuan ini diperkuat dan dipertajam dengan adanya perlindungan terhadap pasien dengan mengatur jaminan perlindungan keamanan data rekam medis yang tertuang dalam Pasal 79 dari Undang-undang Praktik Kedokteran yang menyebutkan adanya sanksi pidana berupa hukum penjara paling lama satu tahun dan denda dalam bentuk materi paling 
banyak sebesar Rp 50.000.000,00 (lima puluh juta rupiah) bagi dokter dan dokter gigi yang tidak membuat rekam medis sebagaimana aturan yang berlaku (Depkes RI, 2004)

Sebenarnya dalam Praktik Kedokteran Indonesia, rekam medis terbagi menjadi dua yaitu rekam medis asli yang dipegang oleh rumah sakit yang hanya dapat dibuka oleh perintah persidangan (dalam hal ini hakim) atau perintah perundang-undangan dan bagian resume medis yang berisikan data ringkasan rekam medis pasien yang dapat dibawa pasien kemanapun dia pergi sebagai sarana penyampaian informasi kondisi kesehatan pasien antar institusi yang secara hukum tidak terlalu bersifat mengikat dan dapat dibuka asalkan dengan seizin pasien. Menurut Permenkes No. 269/MENKES/ PER/III/2008 Bab II pasal 4 menyebutkan bahwa: ringkasan pulang atau resume medis dibuat oleh dokter atau dokter gigi (Pasal 3 bulir 2) dan berisikan data berupa identitas pasien, diagnosis masuk serta indikasi pasien dilakukan perawatan, ringkasan dari hasil pemeriksaan objektif (fisik dan penunjang), diagnosis keluar/ akhir, pengobatan dan tindakan medis yang telah dilakukan, serta penanda dari dokter atau dokter gigi yang membuat resume medis tersebut (nama, paraf, dan tanda tangan) (Pasal 3 bulir 1) (Kementerian Kesehatan Republik Indonesia, 2008)

Secara hakekat pasien memiliki hak untuk merahasiakan dan memiliki kepastian untuk tetap merahasiakan penyakitnya serta kondisi medis terkait sebagai bagian dar aspek hukum privat dan hal ini diatur dalam Pasal 32 huruf "i" UU No. 44 tahun 2009 tentang Kesehatan yang menjelaskan bahwa pasien berhak untuk mendapatkan kerahasiaan atau privasi perihal penyakit atau keadaan medis yang dideritanya.(Republik Indonesia, 2009a)

Beralih ke masa Pandemik Covid-19 yang mengundang keresahan di masyarakat luas yang mendorong penuntutan akan keterbukaan informasi secara cepat dan akurat menjadi sebuah sesuatu yang harus mendapatkan perhatian pemerintah dikarenakan beberapa alasan diantaranya (1) era globalisasi menuntut pemerintah untuk membuka diri akan keterbukaan infromasi, (2) Implikasi dari Penegakan Hak Asasi Manusia yang membutuhkan informasi. (3) Kemajuan ilmu teknologi dan kemudahan akses informasi akan keterbukaan informasi; (4) Adanya tuntutan untuk menciptakan "good governance" dengan syarat utama berupa keterbukaan informasi kepada publik. Hukum publik sendiri sebenarnya telah mengatur mengenai keterbukaan publik dan hal ini tertuang dalam Undang-Undang Nomor 14 tahun 2008 tentang Keterbukaan Informasi yang dalam implentasinya haruslah sejalan dengan UU No. 36 Tahun 2009 tentang Kesehatan terutama tertuang dalam pasal 169 UU Kesehatan yang mengatur bahwa pemerintah akan memberikan kemudahan untuk memperoleh akses informasi khususnya informasi kesehatan kepada masyarakat guna meningkatkan derajat dan pengetahuan masyarakat. (Republik Indonesia, 2009b)

Permasalahan mulai timbul ketika dimana terjadi situasi penularan penyakit yang massif dan pemerintah tetap didorong untuk menciptakan pemerintahan yang baik dengan tetap menyelanggarakan keterbukaan informasi kepada publik tanpa harus mengesampingkan hak privat yang bersifat rahasia dalam hal ini adalah rekam medis. Pada masa pandemic Covid-19 tanpa ada kepastian kapan dan dimana masa pandemic ini selesai tanpa adanya vaksin sebagai "juru selamat" dalam menanggulangi pandemic ini maka pemerintah selaku regulator dituntut untuk melakukan vaksin sosial dimana yang bersifat non medis yang diantaranya mengandung Langkah-langkah komunikasi informatif mengenai pengobatan apa saja yang sudah teruji, angka kasus positif Covid-19, angka kematian Covid-19, angka kesembuhan Covid-19, promosi kesehatan, Tindakan pencegahan, protokol penanganan jenazah, regulasi system kesehatan, masa atau waktu karatina dan seluruh informasi terkait yang harus dibuka kepada publik secra akurat, terbuka, dan akuntabel guna mengurangi peningkatan kasus Covid-19 salah satunya adalah pembukaan data rekam medis.

Perspektif lain didalam hukum perlindungan konsumen dan masyarakat merupakan kelompok konsumen dari pelayanan kesehatan. Pandangan konsumen ini dalam system Jaminan Kesehatan Nasional tidak terbatas pada kelompok masyarakat yang sakit tetapi 
kelompok masyarakat yang sehat merupakan anggota kelompok konsumen dari pelayanan kesehatan dalam hal ini masuk dalam kelompok promosi kesehatan masyarakat. Menurut Pasal 4 Ayat (3) Undang-Undang Nomor 8 Tahun 1999 Tentang Perlindungan Konsumen dengan tetap memperhatikan Undang-Undang Nomor 44 Tahun 2009 Tentang Rumah Sakit yang mengatur bahwa hak konsumen (masyarakat dan pasien) adalah mendapatkan informasi yang jujur, jelas, dan benar mengenai kondisi dari jasa dan atau barang; serta dengan hubungannya dengan kesehatan adalah mengenai konsumen berhak atas informasi yang jujur serta jelas dalam menerima layanan kesehatan serta dalam hal ini fasilitas kesehatan (Rumah Sakit) merupakan ujung tombak dari pelayanan kesehatan (Kemenkes RI, 1999)

Dari seluruh penjelasan diatas diketahui bahwa rekam medis sendiri merupakan bagian dari aspek hukum private yang dalam pelepasan datanya membutuhkan izin dari pemilik serta peraturan perundang-undangan. Hal ini disebabkan karena data identitas diri pasien merupakan sebuah aspek yang tidak seperti hukum publik yang dalam hal ini tidak berkaitan dengan informasi umum seperti penularan penyakit, promosi kesehatan, dan lainnya. Mendelik sisi lain diketahui di masa Pandemi Covid-19 ini terjadi dorongan akan keterbukaan informasi medis secara akurat dan transparan dengan tujuan dasar awal adalah untuk menekan angka penularan, dengan konsekuensi mencederai kepentingan pribadi dimata hukum. Penelusuran analisa mendalam menggunakan asas kepentingan umum diatas kepentingan pribadi diketahui pembukaan data rekam medis selama dalam batas perundang-undangan menjadi sebuah hal yang dalam tanda kutip adalah baik guna menekan angka kejadian penyebaran Covid-19. Hal ini terkutip dalam pendapat Warella yang membahas "Kepentingan pribadi dan publik berada dalam garis kontinum yang secara dinamis berubah sesuai dengan situasi yang dihadapi. Pemerintah sebagai penjaga kepentingan umum harus mengimbangi kedua kepentingan tersebut. Berdasarkan filosofi negara dan nilai-nilai masyarakat, pemerintah harus mengutamakan kepentingan umum daripada kepentingan pribadi yang sempit, dan menunjukkan prinsip tersebut dalam kebijakannya. Para pejabat negara harus menunjukkan dan melaksanakan prinsip ini. Kepentingan publik harus dijamin dengan supremasi hukum, dengan menunjukkan komitmen yang kuat pada prinsip "tidak ada yang di atas hukum”. Oleh karena itu, penyelenggaraan pemerintahan yang baik merupakan suatu keharusan untuk mewujudkan pelayanan yang prima kepada masyarakat." Keseluruhan asas ini dipertimbangkan satu sama lain dengan permasalahan berikutnya adalah implementasi kebijakan tersebut kedalam pelaksanaanya

\section{Evaluasi Sebagai Jalan Tengah dalam Mengatasi Konflik Kepentingan akan Keterbukaan Informasi dan Kerahasian Identitas Pasien Covid-19}

Penanganan pandemic Covid-19 sekarang ini menjadi sebuah hal yang penting serta tidak hanya menyangkut konsep penyembuhan pasien tetapi mengurangi pula angka penyebaran virus guna menekan angka kasus baru dikemudian hari. Salah satu jalan alternatif yang dapat digunakan adalah dengan cara melakukan pemanfaatan data-data strategis serta actual guna mendukung kesinambungan penanganan pandemik yang mendorong potensi mencederai kepentingan pribadi. Saat ini pemerintah Indonesia memberlakukan membukaan data rekam medis yang bersifat sangat terbatas perihal data rekam medis penderita Covid-19 dengan hanya memberikan data berupa nomor kasus, umur, dan wilayah tempat tinggal. Hal ini mendorong permasalahan dorongan dan tekanan masyarakat akan keterbukaan informasi publik yang mendorong kebocoran data rekam medis yang bersifat sangat rahasia serta berpotensi menimbulkan permasalahan lebih lanjut seperti pengusiran penderita Covid-19 dari tempat tinggal atau domisili serta larangan penguburan bagi jenazah Covid-19.

Bercermin dari seluruh kasus diatas sebenarnya pemerintah Indonesia telah menerapkan kebijakan penanganan Covid-19 yang tidak berbeda signifikan seperti yang telah di anut negara lain dengan cerminan bahwa (OECD, 2020) 
a. Negara Republik Korea yang menerapkan "Big Data" guna merekam seluruh data rekam medis pasien denga tujuan menekan angka penyebaran penyakit

b. Singapura yang cenderung mengumpulkan seluruh data relevan Covid-19 tanpa persetujuan dengan tidak membuka ke publik secara gambling

c. Beberapa negara lain yang tidak membuka data ke publik walaupun sudah memberikan label suspect

d. Hanya memberikan nomor kasus pada penderita Covid-19

Dalam penanganan Covid-19 di negara lain adalah negara lain tersebut sangat menjamin dan menunjung tinggi perlindungan data pribadi pasien meskipun kebijakan pengaksesan data diri secara sepihak oleh pemerintah tetap dilaksanakan guna melakukan Tindakan penelusuran terkait deteksi dini dan pencegahan penularan Covid-19. Dualisme ini dinilai cukup adil dikarenakan manfaat yang dihasilkan dari kebijakan ini dinilai lebih besar daripada efek merugikan yang didapat, Hal ini sesuai dengan kepentingan umum diatas kepentingan pribadi dengan tidak mengesampingkan asas menfaat lebih tinggi daripada efek samping.

Indonesia sendiri dalam prakteknya memberlakukan prinsip proporsionalitas, necessities, dan purposive limitation dalam penanganan regulasi data pasien Covid-19 terkonfirmasi yang memiliki makna bahwa terdapat sebuah batas ketentuan dalam pengambilan dan akses data rekam medis dengan tidak mengesampingkan efek keadilan guna tujuan yang besar-besarnya dengan regulasi kebijakan yang lebih baik bilamana hal ini dlakukan dengan sepengetahuan pemilik data tersebut.

\section{Kesimpulan}

Penelusuran literatur di atas memiliki beberapa kesimpulan utama yaitu COVID-19 berdampak sangat luas terhadap seluruh aspek kehidupan manusia terutama dibidang sosial, kesehatan, dan ekonomi. COVID-19 juga menyebabkan berbagai permasalahan konflik kepentingan di berbagai sector salah satunya adalah hak privasi dan transparansi informasi publik. Hal ini menyebabkan dilemma dikarenakan pencederaan hak privasi di masa pandemic COVID-19 akan menyebabkan stigmatisasi dan Tindakan persekusi, tetapi disisi lain pencederaan dari segi transparansi informasi publik akan berdampak terhadap lambatnya penanganan COVID-19. Tetapi di era pandemic Covid-19 ini disertai dengan dorongan masyarakat akan keterbukaan informasi publik mendorong asas kepentingan publik harus dijamin dengan supremasi hukum, dengan menunjukkan komitmen yang kuat pada prinsip "tidak ada yang di atas hukum". Oleh karena itu, penyelenggaraan pemerintahan yang baik merupakan suatu keharusan untuk mewujudkan pelayanan yang prima kepada masyarakat. Implementasi lebih lanjut dari kebijakan ini oleh Pemerintah selaku regulator menjadi penting guna memfasilitasi kepentingan publik dengan tidak mencederai hak individu.

\section{Daftar Pustaka}

AHC Media. (2020). Beating the Pandemic: What Emergency Providers Should Know About COVID-19. Pediatric Emergency Medicine Reports.

Bajpaii, N. (2020, May 13). Noida DM performs last rites of COVID-19 victim as relatives refuse to receive body. The New Indian Express.

Bezanson, R. P. (2017). The Right to privacy revisited: Privacy, news, and social change, 18901990. In Privacy. https://doi.org/10.2307/3480738

Bharat, S. (2011). A systematic review of HIV/AIDS-related stigma and discrimination in India: Current understanding and future needs. SAHARA-J: Journal of Social Aspects of HIV/AIDS, 8(3), 138-149. https://doi.org/10.1080/17290376.2011.9724996 
Bhattacharya, P., Banerjee, D., \& Rao, T. S. (2020). The "Untold" Side of COVID-19: Social Stigma and Its Consequences in India. Indian Journal of Psychological Medicine, 42(4), 382-386. https://doi.org/10.1177/0253717620935578

Chavan, V. (2020, May 8). Obstruct last rites of COVID-19 victims, face criminal charges. Pune Mirror, 1.

Connell, R. (2020). COVID-19/Sociology. Journal of Sociology. https://doi.org/10.1177/1440783320943262

Depkes RI, 2004. (2004). UU No. 29 Tahun 2004 Tentang Praktik Kedokteran. Aturan Praktik Kedokteran, 157-180.

Dewi, S. (2016). Konsep perlindungan hukum atas privasi dan data pribadi dikaitkan dengan penggunaan. Yustisia, 5(1), 33-40.

Ibrahim, J. (2006). Teori \& Metodologi Penelitian Hukum Normatif. In Teori Metodologi Penelitian a.

Kemenkes RI. (1999). Undang - Undang Refublik Indonesia Nomor 8 Tahun 1999 Tentang Perlindungan Konsumen. 80.

Kemenkes RI. (2020). Situasi COVID-19. Kementrian Kesehatan RI. https://doi.org/10.1017/CBO9781107415324.004

Kementerian Kesehatan Republik Indonesia. (2008). PERMENKES RI No 269/MENKES/PER/III/2008. In Permenkes Ri No 269/Menkes/Per/Iii/2008 (Vol. 2008, p. 7).

Kementerian Kesehatan Republik Indonesia. (2020). Pedoman Kesiapsiagaan Menghadapi Coronavirus Disease (COVID-19). Direkorat Jenderal Pencegahan Dan Pengendalian Penyakit.

Krishnatray, P. (2020, May 12). COVID-19 is leading to a new wave of social stigma. The Wire, 1. https://thewire.in/society/covid-19-\%0Asocial-stigma

Kumar, C., \& Mohanty, D. (2020, May 11). Migrant workers battle stigma, bias back home. Hindustan Times, 1.

Mertokusumo, S. (2005). Mengenal Hukum Suatu Pengantar (1st ed.). Liberty.

OECD. (2020). Ensuring data privacy as we battle COVID-19. OECD Policy Responses to Coronavirus, April, 1-4. https://doi.org/10.1787/276aaca8-en

Patel, M., Kute, V., \& Agarwal, S. (2020). "Infodemic" of COVID 19: More pandemic than the virus. In Indian Journal of Nephrology. https://doi.org/10.4103/ijn.IJN_216_20

Presiden Republik Indonesia. (2020a). Keputusan Presiden RI Nomor 11 Tahun 2020. Penetapan Kedaruratan Kesehatan Masyarakat, 031003.

Presiden Republik Indonesia. (2020b). Peraturan Pemerintah Nomor 21 Tahun 2020 tentang Pembatasan Sosial Berskala Besar Dalam Rangka Percepatan Penanganan Coronavirus Disease 2019/COVID-19. 2019(022868), 8.

Priscyllia, F. (2019). Perlindungan Privasi Data Pribadi dalam Perspektif Perbandingan Hukum. Jatiswara, 34(3), 1-5. https://doi.org/10.29303/jatiswara.v34i3.218

Ram, T. (2020, May 13). Branded "super spreader," family of Karnataka COVID-19 victim battles stigma. https://www.thenewsminute.com/article/\%0Abranded-super-spreaderfamily-karnataka-\%0Acovid-19-victim-battles-stigma-124482

Ravianto. (2020, April 29). Kasus Pengusiran 3 Tenaga Medis dari Tempat Kos, RSUD Langsung Lapor Polisi, Ini Pembelaan Ibu Kost. Jabar Tribun News. https://jabar.tribunnews.com/2020/04/29/kasus-pengusiran-3-tenaga-medis-daritempat-kos-rsud-langsung-lapor-polisi-ini-pembelaan-ibu-kost

UNDANG-UNDANG REPUBLIK INDONESIA NOMOR 14 TAHUN 2008 TENTANG KETERBUKAAN INFORMASI PUBLIK, 276 (2008).

Republik Indonesia. (2009a). Undang Undang No. 44 Tahun 2009 Tentang Rumah Sakit. 128. 
Republik Indonesia. (2009b). UU No. 36 Tahun 2009 tentang Kesehatan. 1-8.

Republik Indonesia. (2014). Undang-Undang RI Nomor 36 Tahun 2014 tentang Tenaga Kesehatan. In Presiden Republik Indonesia (pp. 1-78). http://www.pdpersi.co.id/diknakes/data/regulasi/undang_undang/uu362014.pdf

Rosenbaum, L. (2020). Facing covid-19 in Italy - Ethics, logistics, and therapeutics on the epidemic's front line. In New England Journal of Medicine. https://doi.org/10.1056/NEJMp2005492

Sampurno, M. B. T., Kusumandyoko, T. C., \& Islam, M. A. (2020). Budaya Media Sosial, Edukasi Masyarakat, dan Pandemi COVID-19. SALAM: Jurnal Sosial Dan Budaya Syar-I. https://doi.org/10.15408/sjsbs.v7i5.15210

Santhosini, S. (n.d.). What a lockdown means when home is hundreds of miles away. Allside. Retrieved October 13, 2020, from https://www.allsides.com/news/2020-04-141106/what-lockdown-means-when-home-hundreds-miles-away

Satya, P. A. N. I. P. (2020). Covid- 19 Dan Potensi Konflik Sosial. Jurnal Ilmiah Hubungan Internasional, O(0), 39-45. https://doi.org/10.26593/jihi.v1i1.3867.39-45

Sharma, S. (2020, April 10). Kin of COVID-19 dead in Punjab refuse to attend last rites. DownToEarth. https://www.downtoearth.org.in/\%0Anews/health/kin-of-covid-19dead-in-punjab-\%0Arefuse-to-attend-last-rites-70379

Suni, N. S. P. (2020). Kesiapsiagaan Indonesia Menghadapi Potensi Penyebaran Corona. Pusat Penelitian Badan Keahlian DPR RI.

Tejomurti, K., Hadi, H., Imanullah, M. N., \& Indriyani, R. (2019). Legal Protection for Urban Online-Transportation-Users' Personal Data Disclosure in the Age of Digital Technology. PADJADJARAN Jurnal Ilmu Hukum (Journal of Law). https://doi.org/10.22304/pjih.v5n3.a5

Trani, J.-F., Bakhshi, P., Kuhlberg, J., Narayanan, S. S., Venkataraman, H., Mishra, N. N., Groce, N. E., Jadhav, S., \& Deshpande, S. (2015). Mental illness, poverty and stigma in India: a case-control study. BMJ Open, 5(2), e006355-e006355. https://doi.org/10.1136/bmjopen-2014-006355

World Health Organization. (2020). WHO Coronavirus Disease (COVID-19) Dashboard. World Health Organization. 